\title{
Recent Case:
}

\section{the Turkish Decision on Hagia Sofia}

Cem Tecimer (Harvard Law School)

\section{Case Summary}

On July 2, 2020, a division of Turkey's highest administrative appellate court unanimously annulled a 1934 presidential decision by Kemal Ataturk, founding president of Turkey, converting Hagia Sophia (tr. Aya Sofya) into a museum. The Court reasoned as follows: the companion law to Turkey's secular Civil Code had provided that the old (Islamic) law would apply to waqfs (endowments) established before the new Civil Code came into force. The Hagia Sophia was a mosque, the Court found, that constituted part of Fatih Sultan Mehmed's (aka Mehmed the Conqueror) waqf, and under the applicable law at the time, it was forbidden to alter the status of waqf property via administrative decisions. The Court therefore ruled that the Cabinet Decision of 1934 had unlawfully changed the status of waqf property. The Court struck down the Cabinet Decision of 1934, thus paving the way for restoring Hagia Sophia's status as a mosque for worship.

Days later, on July 10, 2020, Recep Tayyip Erdogan issued a decision based on the court ruling, restoring its status as a mosque open to worship and transferring its maintenance to the country's Presidency of Religious Affairs. Following a Turkish administrative court ruling that revoked an earlier administrative decision (1934) converting the mosque into a museum, President Erdogan of Turkey was expected to restore Hagia Sophia's status as a mosque. Upon his decision to restore the site's status as a mosque open to worship, Erdogan personally inspected the site and the preparations to have it ready for the Friday prayer on July 24, 2020. The government quickly named 3 imāms, one a professor of religious studies, for Hagia Sophia. On July 24, 2020, Erdogan, accompanied by top government officials and politicians, participated in the first Friday prayer at the site after 
a 86-year hiatus where he recited passages from the Qur'ān. 350,000 people are estimated to have been in attendance.

Following is an English translation of the entirety of the Council of State's Court Decision No: 2020/2595 in the above summarized Matter No: 2016/16015.

\section{Translation}

Plaintiff: [Redacted]

Counsel: [Redacted]

Respondent: [Redacted]

Counsel: [Redacted]

Matter: The Plaintiff asks that the Cabinet Decision-dated $11 / 24 / 1934$ and numbered 2/1589 - concerning the conversion of the Hagia Sophia Mosque into a museum be annulled, on which the decision of the 1 st Regional Directorate of the Prime Ministry's Directorate General of Foundations - dated 10/19/2016 and numbered 27882 - to deny plaintiff's request to the Prime Ministry that Hagia Sophia be reopened to worshipdated 08/31/2016 - is based. Plaintiff's Contention: Plaintiff requests that the Cabinet Decision of 1934 be annulled, and asserts accordingly that the signatures under the Cabinet Decision of 1934 be submitted to a graphology test; that the Decision was not published in the Official Gazette and submitted to the Council of State for inspection, in contravention to Article 52 of the Turkish Constitution of 1924; that some of the ministers whose signatures appear under the Decision are proven by parliamentary minutes to have been outside of Ankara at the time of the Decision; that Hagia Sophia's deed mentions the word "mosque" and not "museum" and that it is not described as a museum on UNESCO's official website; that Hagia Sophia, as a waqf property, needs to be used in accordance with its foundation charter [waqfiyyah; tr. vakfiye]; that the will of the endower is being disregarded; and that there is no decision taken to assign Hagia Sophia to the Ministry of Culture and Tourism. 
Respondent Government Agency's (no longer active) Defense: Respondent requests that the case be dismissed on the grounds that there can be no litigation years later against a Cabinet Decision put into effect in 1934; that the timing of the suit is late; that the Plaintiff, from time to time, applies to the Prime Ministry and other agencies regarding Hagia Sophia and that the application here is identical to their previous one; that there were various cases against the Cabinet Decision in question and that a previous case by the Plaintiff was dismissed and that decision had become final; that there exists a final judgment on the matter; that the Hagia Sophia Mosque is registered under the waqf charter of Mehmed II son of Murad II dated 1470, in lot no. 7, block no. 57, section no. 57, as "The Honorable Mosque of Grand Hagia Sophia inclusive of a tomb, properties rented out, a clock-house, and a madrasa" and that said waqf is a registered waqf with its own legal personality governed and represented by the Directorate General of Foundations; that the Cabinet is the highest administrative decision-making body of government to make general administrative decisions; that the Cabinet is authorized to make any administrative decision as long as it is based on a law and does not contravene the Constitution and laws; that altering Hagia Sophia's status and manner of use falls under the executive's discretion; that the Cabinet may make a decision to that end at any time pursuant to national and international circumstances and our domestic legal framework; that the allegation that the signatures under the Cabinet Decision are forged is false.

Council of State Investigating Judge's Opinion: Is of the opinion that the Cabinet Decision in question be annulled. Council of State Prosecutor's Opinion: Plaintiff asks that the Ataturk signature under the Cabinet Decision dated 11/24/1934 and numbered 2/1589 concerning the conversion of the Hagia Sophia Mosque into a museum be examined at a criminology laboratory and annulled.

It has come to our attention that, before the instant case, a prior case by the Plaintiff with the same request was rejected by the Tenth Chamber of the Council of State in its decision 
dated 03/31/2008 and numbered E:2005/125, K:2008/1858; and that said decision was upheld, with a different reasoning, by the Council of Chambers of Administrative Matters in its decision dated 12/10/2012 and numbered E:2008/1775 and numbered K:2012/2639; and that Plaintiff's request for revision of decision was denied by the decision dated 04/06/2015 and numbered E:2013/3803, K:2015/1193.

Thus, it must be accepted that Plaintiff must have been notified of the Cabinet Decision dated 11/24/1934 and numbered $2 / 1589$, at the latest, by the time the aforementioned case was commenced, and since there have not arisen any novel legal circumstances that would give rise to a right to commence a late legal action, there is no possibility to proceed with the case due to the statute of limitations.

As for the substance of the matter:

After examining the case file, it is understood that the immovable consisting of 2 hectares and $6644 \mathrm{~m} 2$ in the City of Istanbul, District of Eminonu, Cankurtaran Neighborhood, Bab-i Humayun Street, in lot no. 7, block no. 57, section no. 57, which includes the Hagia Sophia Mosque, was registered in the name of the Fatih Sultan Mehmet Waqf on 11/19/1936; that the Ministry of Education had requested, through its letter dated 11/04/1934 and numbered 94041, that the Hagia Sophia Mosque, a unique architectural and aesthetic monument, be converted into a museum, the shops belonging to the waqf be demolished, the rest be expropriated and refurbished and that the Directorate allot a certain amount that year and the following year for its reparation and permanent protection; that the Directorate General of Foundations appraised the monetary situation of the waqf in its letter dated 11/07/1934 and numbered 153197/107; that the Cabinet Decision dated 11/24/1934 and numbered 2/1589 decided that the buildings belonging to the waqf surrounding the Hagia Sophia Mosque be demolished by the Directorate General of Foundations and that the Hagia Sophia Mosque be converted into a museum by expropriating and demolishing other buildings and repairing and preserving others, to be compensated by 
the Ministry of Education.

On 16 November 1972, The UNESCO General Conference has adopted the Convention Concerning the Protection of the World Cultural and Natural Heritage in order to identify and introduce cultural and natural sites with universal values accepted as humanity's shared heritage; to raise society's consciousness on preserving this universal heritage; and to ensure the necessary cooperation to preserve cultural and natural sites that are damaged and destroyed for various reasons. This Convention, to whose accession we have provided assent through the Law dated 04/14/1982 and numbered 2658, was adopted by the Cabinet Decision dated 05/23/1982 and numbered 8/4788 and published in the Official Gazette dated 02/14/1983 and numbered 17959.

In its Preamble, the Convention emphasizes that it was adopted noting that "the cultural heritage and the natural heritage are increasingly threatened with destruction not only by the traditional causes of decay, but also by changing social and economic conditions which aggravate the situation with even more formidable phenomena of damage or destruction"; that "deterioration or disappearance of any item of the cultural or natural heritage constitutes a harmful impoverishment of the heritage of all the nations of the world"; "protection of this heritage at the national level often remains incomplete because of the scale of the resources which it requires and of the insufficient economic, scientific, and technological resources of the country where the property to be protected is situated"; that "the Constitution of the Organization provides that it will maintain, increase, and diffuse knowledge, by assuring the conservation and protection of the world's heritage, and recommending to the nations concerned the necessary international conventions"; that "the existing international conventions, recommendations and resolutions concerning cultural and natural property demonstrate the importance, for all the peoples of the world, of safeguarding this unique and irreplaceable property, to whatever people it may belong"; that "parts of the cultural or natural heritage are of outstanding interest and therefore need to be preserved as part of the world heritage of mankind as a whole"; that "in view of 
the magnitude and gravity of the new dangers threatening them, it is incumbent on the international community as a whole to participate in the protection of the cultural and natural heritage of outstanding universal value, by the granting of collective assistance which, although not taking the place of action by the State concerned, will serve as an efficient complement thereto"; that "it is essential for this purpose to adopt new provisions in the form of a convention establishing an effective system of collective protection of the cultural and natural heritage of outstanding universal value, organized on a permanent basis and in accordance with modern scientific methods."

The World Heritage List, created in accordance with Convention articles, shows natural and cultural sites identified by UNESCO's World Heritage Committee and whose protection is guaranteed by the country in which they are located. The purpose of creating such a list is to enable international cooperation to preserve sites that are the heritage of humanity. The lists, which is regularly updated, has 851 sites from 141 countries as of 2008. 660 of these are cultural, 166 are natural, and 25 are both cultural and natural sites. Istanbul's historic sites were added to the World Heritage List as cultural sites on 12/06/1985.

The use of Hagia Sophia, which is among the most important parts of Istanbul's historic sites and has universal values accepted as common heritage, as a museum falls under the government's discretion and as such there is no illegality in the Cabinet Decision under question.

Plaintiff requests that the Ataturk signature under the Cabinet Decision concerning the conversion of the Hagia Sophia Mosque into a museum dated 11/24/1934 and numbered $2 / 1589$ be submitted to a criminology laboratory for inspection. This request should be denied as, from examining the case file, it becomes clear that the Decision was prepared by the Cabinet pursuant to the Letter from the Directorate of Decisions of the Prime Ministry of the Republic of Turkey dated 11/14/1934 and numbered 94041, and that the President had signed the Decision, and that the Museum had begun operations on 02/01/1935. 
For the foregoing reasons, it is opined that the case ought to be dismissed.

\section{ON BEHALF OF THE TURKISH NATION}

The Tenth Chamber of the Council of State, the adjudicating body of the dispute, began proceedings on 07/02/2020, the date of which parties were notified in advance, after taking notice of the presence of [Redacted] representing the Plaintiff Association and Plaintiff's Counsel [Redacted], Legal Consultant [Redacted] representing [Redacted], the Council of State Prosecutor; both parties were allowed to present their contentions and responses; the Council of State Prosecutor's opinion and parties' reaction thereto were heard; the hearing was then terminated.

Regarding Plaintiff's allegations that the signatures under the Cabinet Decision are forged, that some of the Ministers whose signatures appear under the Decision have been proven to have been outside of Ankara at the time of the Decision, as evidenced by parliamentary minutes, that the signatures need to be submitted for graphological evaluation: it has been decided that there is no need to have the signatures under the Decision be examined for their veracity, since the decision has been reached that there are insufficient indications in the case file that would necessitate such examination.

\section{REgaRding RESPONDENT'S CONTENTION THAT THE STATUTE OF LIMITATIONS APPLIES:}

Article 7, paragraph 1 of the Administrative Procedure Law numbered 2577 provides that the right to commence an action, save separate timelines provided by special laws, is 60 days before the Council of State and administrative courts and 30 days before tax courts; paragraph 4 provides that, for administrative decisions requiring publication, the timeline begins the day after publication, but if the decision requires execution, interested parties can commence an action against either the decision or the executive action or both; Article 10 of the same Law provides 
that interested parties may apply before administrative authorities to have a decision executed or an action taken that can constitute the subject matter of an administrative suit, that if there is no response within 60 days the application will be considered to have been denied, and that interested parties may sue before the Council of State, administrative or tax courts, depending on the subject matter, after said 60 days [for the authority to respond to plaintiff's request] expire and within the statute of limitations.

In the present dispute, the Plaintiff Association has requested that the Hagia Sophia Mosque be opened to worship in accordance with their rights, the law, and the waqf charter, via their petition dated 08/31/2016 registered in the Prime Ministry's general documents registry: "that it is impossible for the Hagia Sophia Mosque to be a museum both legally and from a waqf perspective; that the Law on the Assignment of Historic and Architecturally Valuable Old Waqf Artifacts to the Directorate General of Foundations takes precedence over the Cabinet Decision; that the rule of law is ensured by the Turkish Constitution." The petition was responded to and denied by the letter of the 1st Regional Directorate of the Prime Ministry's Directorate General of Foundations dated 10/19/2016 and numbered 27882: "that, although the ownership of the Hagia Sophia Mosque belongs to the Directorate General of Foundations, in accordance with the Cabinet Decision in dispute dated 11/24/1934 and numbered $2 / 1589$, it has been converted into a museum under the responsibility of the Ministry of Culture and Tourism."

The application made by the Plaintiff Association to the Prime Ministry is one under the scope of Article 10 of the Administrative Procedure Law numbered 2577 and concerns the allegation that Hagia Sophia's status as a museum is contrary to law and the waqf charter and requests that it be opened as a mosque. The Plaintiff Association was notified of the denial of their application, according to the certified letter of notice in the annex of the case file, on 10/24/2016 and the present action has been commenced within the 60-day statutory limit on $12 / 20 / 2016$. While the case before our Chamber numbered E:2018/3786 concerning the annulment of the Cabinet Deci- 
sion has been dismissed on 09/13/2018 with decision number $\mathrm{K}: 2018 / 2588$, since it was commenced without first applying to the sued government agency and without an individual administrative decision on the matter, the present case has been processed without dismissal because it rests on an individual decision [of denial by administrative authorities].

The decision of denial concerning Plaintiff Association's application rests upon the disputed Cabinet Decision. Therefore, following the individual decision [of denial], which is an administratively actionable matter, plaintiff may file a case against either this decision or the decision on which the individual decision [of denial] rests [i.e., Cabinet Decision], or both, and in the present dispute, plaintiff has timely filed suit against the Cabinet Decision upon receipt of the individual decision [of denial]. For this reason, the statute of limitations objection by the sued government agency is without merit.

\section{AS FOR RESPONDENT'S CONTENTION THAT THERE IS ALREADY A FINAL JUDGMENT ISSUED BY OUR CHAMBER ON THE SAME MATTER AND CONCERNING THE SAME PARTIES:}

The final judgment contention concerns the decision of the Council of Chambers of Administrative Matters dated 12/10/2012 and numbered E:2008/1775 and numbered $\mathrm{K}: 2012 / 2639$ that upheld, with a different reasoning, the decision of dismissal of the Tenth Chamber of the Council of State dated 03/31/2008 and numbered E:2005/125, K:2008/1858.

In said decision, the decision to dismiss was upheld for the following reason: "... It is clear that the government of the Republic of Turkey, in accordance with Convention provisions, will have to protect and preserve Hagia Sophia, included in the World Heritage List and accepted as humanity's shared heritage. There is nothing in the Convention that prohibits a determination on the use of Hagia Sophia in accordance with our domestic law, as long as that determination accords with the principle of protection and preservation. 
Respondent government agency has stated that it is necessary to evaluate Hagia Sophia differently than other mosques given its historical, architectural, and cultural qualities and for its protection; that its manner of use has been determined by the Decision under question as a museum in light of these necessities and under the national and international exigencies of 1934.

It also falls under the government's discretion to discontinue Hagia Sophia's use as a museum and to assign it a different purpose, in light of changes in national and international circumstances, and in accordance with the purpose to protect and preserve Hagia Sophia's historical, architectural, and cultural qualities...."

In said decision, after mentioning that there is no provision in the Convention Concerning the Protection of the World Cultural and Natural Heritage prohibiting a determination on how to use Hagia Sophia pursuant to our domestic law, it has been decided that assigning Hagia Sophia a different status other than a museum is within the government's discretion. However, the substance of that case did not involve any allegations, substantive evaluations, reasonings or decisions concerning Hagia Sophia's ownership, its waqf status, and whether it is against the law to use it for a purpose other than the one delineated in its charter.

Thus, it is necessary to substantively evaluate the new and different application made by Plaintiff pursuant to Article 10 of the Law numbered 2577, which concern contentions not adjudicated beforehand and on which there exist no prior judgments or decisions; thus, it is not possible to state that there is a final judgment on the matter already; thus the procedural objection by Respondent government agency is without merit, and after hearing from the Investigating Judge, [we have] proceeded to the substance of the matter: 


\section{FACTS AND PROCEDURAL POSTURE:}

Plaintiff's representative applied to the (now defunct) Prime Ministry with a petition dated 08/31/2016 to have Hagia Sophia, registered under the waqf charter of Mehmed II son of Murad II dated 1470 as a "mosque," and according to the deed dated 11/19/1936, located in the City of Istanbul, District of Eminonu, Cankurtaran Neighborhood, Bab-i Humayun Street, in lot no. 7, block no. 57, section no. 57, as "The Honorable Mosque of Grand Hagia Sophia inclusive of a tomb, properties rented out, a clock-house, and a madrasa" under the name of "Ebulfetih Sultan Mehmet Waqf," opened to worship.

The 1st Regional Directorate of the Prime Ministry's Directorate General of Foundations responded to said petition with a letter dated 10/19/2016 and numbered 27882 that the Hagia Sophia Mosque continues to operate as a museum, and this letter was delivered to Plaintiff on 10/24/2016, and then the present case was commenced through a petition registered on 12/20/2016.

\section{EVALUATION AND REASONING:}

\section{a) Applicable Law:}

Article 1 of the repealed Law on the Application and Enforcement of the Civil Code numbered 864 provides: "Events that preceded the entry into force of the civil code shall be governed by law applicable at the time of occurrence of said events. Thus, regarding events that have occurred before 4 October 1926, even after said date, the law applicable at the time of occurrence of sad events shall govern." Article 8 provides: "A separate enforcement law shall be passed concerning waqfs established before the entry into force of the civil code."

Similarly, Article 1 of the Law on the Application and Enforcement of the Turkish Civil Code dated 12/03/2001 and 
numbered 4722, which repealed Law numbered 864, provides: "The law applicable at the time shall be applied to the legal consequences of events that have preceded the entry into force of the Turkish Civil Code. Whether events that have taken place before the entry into force of the Turkish Civil Code are legally binding in their consequences shall be governed, even after the passage of this law, in accordance with the law applicable at the time of occurrence of said events."

Article 10 of the Waqf Law dated 06/05/1935 and numbered 2762 provides: "Those waqfs whose use for their established purposes contravenes law or public policy or have become useless can be assigned to other establishments or can be traded with money or tangible property upon the offer of the waqf board of directors and decision of the cabinet. Works of architectural or historical value cannot be sold."

Article 15 of the Waqf Law dated 02/20/2008 and numbered 5737, which is still in force, provides: "The immovables of waqfs cannot be confiscated or pledged and no statute of limitations shall apply to institute proprietary interests thereon. Those waqfs that belong to the Directorate

General and that have lost their ability to be used in accordance with their establishment purpose or those whose use contravenes public policy or whose use completely or partially as a waqf has become impossible can be transformed into another waqf, be assigned to another waqf, or converted into money upon the request of the waqf's board of directors and decision of the waqf's general assembly. If converted into money, that money shall be assigned to a different waqf. For transfers within the same waqf, no fee of transfer shall be paid." Article 16 provides: "The Directorate General shall first assign a purpose to the waqfs, in line with their establishment purpose. Those waqfs that cannot be put to use by the Directorate General can be rented until they are used in accordance with their principal purpose. These waqfs can be assigned to public institutions or public associations with a similar purpose to be used in line with the waqf charter and be restored and repaired by the assignees under the supervision of 
the Directorate General."

\section{B) The Institution OF WaQF}

Waqfs, whose roots go back to Islamic law, essentially mean the assignment, by the will of the endower, of property from private possession to public use by prohibiting proprietary interests over said property so that the benefits accruing therefrom can be put to social and cultural use, as emphasized in the decision of the Constitutional Court dated 12/04/1969 and numbered E:1969/35, K:1969/70 and its decision dated 12/26/2013 and numbered E:2013/70, K:2013/166.

Article 101 of the Turkish Civil Code dated 11/22/2001 and numbered 4721 defines waqfs as "congregation of property with legal personality that result from the assignment by real or legal persons of sufficient property or rights for a defined and indefinite purpose."

While it is possible to establish waqfs today, under the provisions of the Turkish Civil Code numbered 4721, regarding waqfs that have been established prior to the entry into force of said law, and taking into account their historical qualities, the reasons for their establishment and the purposes and conditions delineated in their charters and to maintain their continuity; the governance, activities, control, registry of movable and immovable property in and outside of the country, protection, reparation, and preservation and maintenance of their goods for economic purposes of mazbut waqfs, mulhak waqfs, new waqfs, congregational waqfs and esnaf waqfs shall be governed by the Waqf Law dated 02/20/2008 and numbered 5737.

Movable and immovable property that is necessary to provide for the maintenance of the waqf so that the activities and the purposes of the waqfs are realized are called "akar" and property and services provided by waqfs directly to the public for free are called "hayrat." 


\section{c) The Law Applicable to Old Waqfs}

The Turkish Civil Code dated 02/17/1926 and numbered 743 has been published in the Official Gazette dated 04/04/1926 and numbered 339, and in accordance with its Article 936 on its entry into force, entered into force six months later on 10/04/1926.

Article 1 of the repealed Law on the Application and Enforcement of the Civil Code numbered 864, titled "General provisions, the law's retroactivity," provides: "Events that preceded the entry into force of the civil code shall be governed by law applicable at the time of occurrence of said events. Thus, regarding events that have occurred before 4 October 1926, even after said date, the law applicable at the time of occurrence of sad events shall govern." Article 8, titled "Waqfs and establishments preceding the Civil Code," provides: "A separate enforcement law shall be passed concerning waqfs established before the entry into force of the civil code. Establishments whose establishment comes after the entry into force of the Civil Code shall be governed by provisions of the Civil Code." Because it was deemed inappropriate for a waqf established before the entry into force of the Civil Code numbered 743 on 4 October 1926 to be governed by the provisions of the new law, it was stated in Article 8 of the Law numbered 864 that separate legislation would be passed on waqfs established before the entry into force of the Turkish Civil Code and accordingly the Waqf Law dated 06/05/1935 and numbered 2762 was put into force.

Similarly, with the entry into force of the Turkish Civil Code numbered 4721 on 1 January 2002, it was stated in Article 8 of the Law on the Application and Enforcement of the Turkish Civil Code dated 12/03/2001 and numbered 4722, which repealed the Law numbered 864, that without prejudice to waqf laws existing before the entry into force of the Turkish Civil Code numbered 4721, the status of waqfs established before 4 October 1926 would be protected.

Thus, the lawmaker has demonstrated utmost respect for 
the will and freedom of contract of the endowers of old waqfs, has made no change, when regulating old waqfs, with respect to the institution of the waqf and the legal status of its relations and the notion that its property is private property, and has preserved the legal status of waqfs established before the entry into force of the Turkish Civil Code dated 10/04/1926 and numbered 743 via the provisions of the Waqf Law numbered 2762 (still preserved as Waqf Law numbered 5737).

\section{Ç) The Assessment by the Assembly of Civil Chambers of the Court of Cassation on Old Wagfs}

The general assessment by the Assembly of Civil Chambers of the Court of Cassation on waqfs in its decision dated 05/30/2007 and numbered E:2007/18-293, K:2007/310 is as follows:

"The waqf in question is from the Ottoman period. It is therefore necessary to review the case in light of Ottoman waqf law. In Ottoman practice, waqf means to take away a property from possession and dedicate its benefits to charity indefinitely under certain conditions. There is no doubt that waqf is a legal institution, regardless of whether it is private or public. Yet, legal transactions are classified based on whether there exists a unilateral declaration of intent or reciprocal declarations of intent behind them. According to which of these are waqfs established? According to Ottoman jurists, regardless of their public or private status, and regardless of whether there are immediate beneficiaries or not, establishing a waqf requires a unilateral declaration of intent. It is established by the offer (declaration of intent) of the endower [tr. vâkif]. For the offer to become binding, upon adjudication of the matter, the judge must decide that the waqf is necessary [lāzim]. In Ottoman practice, this is called tescil [registration/tasjī1]. For the transaction establishing a waqf to be valid and necessary [Șahịh wa lāzim] tescil is required. Through tescil, all provisions of the act of establishing a waqf become binding on all parties and legal persons. No longer can 
anyone file a suit alleging proprietary claims against the waqf property.... To whom does the waqf property belong after being dedicated to the waqf? Ottoman jurists clearly state that these properties have been transferred to a legal person by invoking the maxim “...in principle, as though Allāh's property...". The legal consequence of the waqf is that the endowed property is locked in and its benefit become the property of all subjects of Allāh. (Ebu-Ula Mardin, Ahkam-i Evkaf [Provisions of Waqfs], Ömer Hilmi Karinabadizade, Ahkamül Evkaf [Waqfs' Provisions].) Through the waqf transaction, the endowed property acquires a certain type of moral inviolability. There can no longer be legal transactions over that property like over ordinary property subject to ownership.... In light of the explanations above, in Ottoman practice, waqf is a legal institution established by a unilateral declaration of intent, whose necessity is decided upon adjudication, whose legal status is expressed through tescil, and whose subject matter consists of a known, determinate, and durable property whose ownership is alienated from the endower and managed by its trustees in accordance with its purpose and to the benefit of real and legal persons.

Whether an Ottoman waqf was established in accordance with the principles above can only be determined upon examination of the waqf charter (vakfiye)."

\section{D) The Decision of the Assembly of Administrative Chambers of the Council of State Concerning the Kariye Mosque}

In the case before our Chamber concerning the annulment of the Cabinet Decision dated 08/29/1945 and numbered 3/3054 on assigning the Kariye Mosque, located in the City of Istanbul, District of Fatih, established before the entry into force of the Turkish Civil Code numbered 743 on 10/04/1926, with mazbut waqf charity status, to the Ministry of Education for use as museum and museum storage, in our decision dated 03/12/2014 and numbered E:2010/14612,K:2014/1474, we have 
dismissed the suit for the following reason: "... that the United Nations Educational, Scientific and Cultural Organization's General Conference has adopted the Convention Concerning the Protection of the World Cultural and Natural Heritage; that this Convention, to which we have assented through the Law dated 04/14/1982 and numbered 2658, adopted by the Cabinet Decision dated 05/23/1982 and numbered 8/4788 has been published in the Official Gazette dated 02/14/1983 and numbered 17959; ... that the World Heritage List, prepared as a result of Convention provisions, shows the natural and cultural sites determined by UNESCO's World Heritage Committee and whose protection has been guaranteed by the states in which they are located; that the aim of preparing such a list is to ensure international cooperation to protect the shared heritage of humanity; that there were 851 sites from 141 countries on the constantly updated list as of 2008; that 660,166 and 25 of these were cultural, natural, and cultural and natural, respectively; that Istanbul's historical sites have been added to the World Heritage List on 12/06/1985 as cultural heritage sites; that the Kariye Museum, which is part of Istanbul's important historical sites and accepted as shared heritage and of universal value, has witnessed history since centuries before until today; that it reflects the important interaction between humanistic values at a certain time period or at a cultural site concerning the development of architecture, technology or architectural art, city planning, and landscape creation; that it presents a valuable example of the architecture or technology or landscape symbolizing one or more important eras of human history; that it is a symbol representing one or more cultures; and therefore that there is no illegality in its use as a museum to properly fulfil its function of being introduced to the word ..."

Upon appeal of our Chamber's said decision, the Council of Chambers of Administrative Matters, in its decision dated 04/26/2017 and numbered E:2014/4645, K:2017/1860, has found the appealed decision consistent with law and procedure and has decided to uphold it; however, Plaintiff, alleging the illegality of the disputed Cabinet Decision, has requested that the decision to uphold dated 04/26/2017 be reviewed, and the ar- 
guments in Plaintiff's petition for review, found consistent with Article 54 of the Law numbered 2577, have been accepted by the Council of Chambers of Administrative Matters, which removed the appeal decision by the Council of Chambers of Administrative Matters dated 04/26/2017 and numbered E:2014/4645, $\mathrm{K}: 2017 / 1860$, and reconvened and decided in its decision dated 06/19/2019 and numbered E:2018/142, K:2019/3130 to remand our Chamber's decision dated 03/12/2014 and numbered E:2010/14612, K:2014/1474 for the following reasons:

"The Honorable Kariye Mosque is an immovable charity endowed in the Ottoman period pursuant to private law provisions to the mazbut Fatih Sultan Mehmet Waqf. Immovable charities [tr. hayrat] are immovables of waqfs which have been established to provide direct services for the public good such as places of worship, hospitals, and kitchens, and these immovables are regarded as public property according to the provisions of both the repealed Waqf Law numbered 2762 and the in-force Waqf Law numbered 5737. Therefore, in essence, private ownership laws are inapplicable to them. Immovable charities cannot be sold, pledged, confiscated, and no statute of limitations granting proprietary interests thereon can be instituted. For these properties are not under the private ownership of anyone, they are assigned to public use and benefit. Immovable charities cannot be assigned a purpose other than the one determined by the waqf, except for the provisions in Article 10 of the repealed Waqf Law numbered 2762 and Articles 15 and 16 of the Waqf Law numbered 5737.

Thus, the disputed Cabinet Decision, taken without the rise of a situation foreseen in Article 10 of the repealed Waqf Law numbered 2762, which disregards the intent and assignment of the endower that the immovable be used as a mosque perpetually, is in violation of Article 1 of Law numbered 864, quoted above, which provides that the law at the time of the issuing of the waqf charter shall be applicable law. Before the disputed Cabinet Decision was taken, in an opinion letter sent from the Minister of Finance to the Prime Ministry, perhaps in anticipation of this legal violation, it was stated that "Therefore, 
the enactment of the draft bill being prepared by the Ministry of Education is awaited," and the Cabinet Decision was taken with reference to a law that had not yet been enacted. When the Respondent government agency was asked of the legal framework governing the dispute, through an interim decision dated $04 / 21 / 2010$ by the Chamber as the case was before the Sixth Chamber of the Council of State, it had been unable to point to any laws.

The foundational quality of a waqf's immovable charities is that they are protected from out-of-purpose use against third persons as well as the state itself. That these waqfs are under the protection of the state does not mean that the state may dispose of waqf properties whenever and as it pleases. The state is merely an entity to whom waqf property is entrusted to ensure that the property is used only in line with its purpose. The assignment of immovable charities for another purpose, even if through an administrative decision, would be unlawful.

Further, when the Cabinet Decision was being made, the stipulations of the Waqf Law numbered 2762 in force at the time were disregarded. Even in the absence of the provisions of the aforementioned repealed Law numbered 864, as the Cabinet Decision was being taken, the stipulations of the legal framework in force at the time of the decision and Article 10 of the Waqf Law enacted on 06/05/1935 and numbered 2762 providing: 'Those waqfs whose use for their established purposes contravenes law or public policy or have become useless can be assigned to other establishments or can be traded with money or tangible property upon the offer of the waqf board of directors and decision of the cabinet,' were disregarded. The same provision is still reiterated in Articles 15 and 16 of the Waqf Law in force numbered 5737.

Yet the disputed Cabinet Decision has been taken without satisfying any of the conditions set out by the Law and neither have procedural requirements been followed. For there is no illegality or contravention to public order in Kariye Mosque's use as a mosque, and there is no decision by the Board of Directors of the Directorate General of Foundations upon which the 
Cabinet Decision could have been based. Moreover, the assignment concerns the use of a place of worship as a museum and a museum storage site, which, even if all other conditions were satisfied, renders the disputed Decision manifestly unlawful because of its purpose.

For the foregoing reasons, the disputed Cabinet Decision is unlawful from the standpoints of its [lack of] authorization, form, reasoning, and purpose."

In accordance with said decision of remand, the Cabinet Decision's sections pertaining to the Kariye Mosque have been annulled by our Chamber's decision dated 11/11/2019 and numbered E:2019/11776, K:2019/7680.

\section{E) The Status of Wagf Property}

According to the Constitutional Court's decision dated 01/30/1969 and numbered E:1967/47, K:1969/9, the property of a waqf never belongs to the state but to the waqf itself: "it is a requirement of Islamic law and the Waqf Law that preserves parts of that law that the immovable property of waqfs established in accordance with Islamic law and whose presence is recognized by the Waqf Law dated 06/05/1935 and numbered 2762 be under the ownership of their waqfs. Thus, waqf property never belongs to the state but to the waqfs themselves."

According to the jurisprudence of the Court of Cassation, too, waqf properties are not owned by the state. In accordance with the Law on the Application and Enforcement of the Civil Code numbered 864, in its decision dated 05/26/1935 and numbered E:1935/78, K:1935/6, the Council on the Unification of Civil Law Precedents has decided that for waqfs established before the entry into force of the Turkish Civil Code numbered 74 , previous law shall be applicable and that waqf properties are not state property: "that old principles shall be applicable to waqfs like this that have been established prior to the entry into force of the Civil Code," "that waqf property is accepted not to 
be among state properties."

\section{F) The General Assessment of WaqfS ESTABLISHED BEFORE 10/04/1926}

In light of the foregoing laws and Constitutional Court, Court of Cassation, and Council of State precedents, concerning waqfs established prior to the entry into force, before 10/04/1926, of the Turkish Civil Code numbered 743, the following conclusions have been reached:

(i) That the vakfiye or the waqf charter is the founding document of the waqf, and that these documents contain regulations concerning the subject matter, purpose, and organs of the waqf, as reflective of the endower's intention,

(ii) That the provisions of the vakfiye or the waqf charter have the binding force and value of the law; that, once the establishment of the waqf has been completed, these provisions bind the endower, the trustees, the beneficiaries, third parties as well as the state and therefore that no one may change the vakfiye or the waqf charter that reflects the intention of the endower,

(iii) That it is obligatory that waqf properties be used in accordance with the intention of the endower.

After the intent to establish a waqf, which is a private law transaction, has been declared pursuant to law, there is no doubt that the congregation of property that now acquires legal personality has the constitutionally guaranteed right to ownership over its properties and rights as well as the right to association with respect to the continuance of its legal personality. Therefore, it is necessary that regulations concerning the private law legal personality of waqfs be consistent with this essential quality of the institution of the waqf, and that decisions taken with regard to waqfs be in accordance with the intent of the endower as well as the right to ownership and association of the Constitution.

Otherwise, in the event that the intent of the endower 
when establishing the waqf is disregarded and the purpose of the endower is transgressed or the purpose or properties of the waqf are altered, there would be no possibility to characterize the waqf as a private law legal personality, and this would contravene the principle of legal certainty as a necessary extension of the rule of law, enshrined in Article 2 of the Constitution, and rules in Articles 33 and 35 of the Constitution on the right to association and ownership.

Thus, in line with the principles summarized above, the lawmaker has provided in the provisional Article 7 of the Waqf Law numbered 5737 that, concerning the immovables of waqfs established before 10/04/1926, those registered in the 1936 Declarations with immovables under nom de guerre or fictitious names, and those bought by congregational endowments after the 1936 Declarations or those that have been bequeathed or donated to congregational waqfs but have been registered under the names of the Treasury, the Directorate General of Foundations, bequeathers or donors, on account of ineligibility to acquire possession, it is possible for waqfs to acquire these properties by application, within 18 months after the passage of the Waqf Law numbered 5737 with all rights and responsibilities in the deeds, to deed registries, upon the recommendation of the Foundation Council Members.

Similarly, through provisional Article 11 added to the Waqf Law numbered 5737 by the Decree dated 08/22/2011 and numbered 651, congregational waqfs can have immovables without any registered owners, immovables registered under the Treasury, the Directorate General of Foundations, municipalities, special provincial administrations - save those expropriated, sold or traded with them-, and graveyards and fountains registered under government agencies, registered back under their names by registry of deeds, if they apply within 12 months after the passage of said article with all rights and responsibilities attached to the deed; those immovables that have been bought by or bequeathed or donated to congregational waqfs but have nonetheless been registered under the Treasury or the Directorate General of Foundations on account of ineligibility to 
acquire possession and are now registered under third persons shall be paid [to congregational waqfs] by the Treasury of the Directorate General of Foundations based on the market value determined by the Ministry of Finance.

Finally, provisional Article 13 added to the Law numbered 5737, through Article 78 of the Law dated 03/21/2017 and numbered 7103 , provides that the immovables located in the city of Mardin, the District of Nusaybin that are listed in the article shall be registered by the relevant registries under waqfs among Assyrian waqfs determined by the Foundation Council.

\section{G) The European Court of Human Rights' (ECHR) Perspective on the Institution of the WaQF}

While the right to establish foundations is not explicitly enshrined in the European Convention on Human Rights, and while Article 11 of the Convention only mentions "the freedom of association," ECHR interprets this article broadly to encompass the right to establish foundations (Sidiropoulos and others v. Greece, no. 26695/95, 07/10/1998, § 40; Mihr Vakfi v. Turkey, no. 10815/07, 05/07/2019, § 40) and finds a close connection between the right to establish foundations and the freedom of conscience and religion in Article 9 and freedom of expression in Article 10 of the Convention (Young, James and Webster v. UK, no. 7601/76; 7806/77, § 57,08/13/1981).

In some individual application cases brought before it by some waqfs, ECHR considers alleged violations of the right to ownership according to Article 1 of Additional Protocol no. 1 and rules that the waqfs be compensated monetarily or property and rights be registered under their name and returned to them. In application made by one of these waqfs, the Waqf of Samatya Surp Kevork Armenian Church, School and Graveyard, founded by a Sultan's decree in the Ottoman period in 1832, ECHR, taking into account the waqf status and the fact that the immovables under question had been registered under the waqf's name for a long time, ruled that the immovables be re-registered un- 
der the waqf's name, and that failing, the waqf be compensated monetarily (Board of Directors of the Waqf of Samatya Surp Kevork Armenian Church, School and Graveyard v. Turkey, no. 1480/03, 12/16/2008).

It is therefore apparent that the ECHR, too, as a result of the protected status of waqfs, guarantees waqfs' immovables and rights as part of the right to ownership, including those waqfs founded during the Ottoman period.

As it is clear that the right ownership extends to using and benefitting the property in question, the intent of the endower with respect to the endowed property and rights must be preserved and regarded with respect to the use of waqf assets. As a necessary consequence, the alteration of the status of a waqf immovable, contrary to the endower's intent, or its use contrary to the intended purpose will contravene ECHR caselaw.

\section{$\breve{G) ~ T h e ~ E x a m i n a t i o n ~ o f ~ t h e ~ D i s p u t e d ~ C a b i n e t ~ D e c i s i o n ~}$}

\section{1) Content}

The Cabinet Decision dated 11/24/1934 and numbered $2 / 1589$ put into force based on the letter of the Directorate General of Foundations dated 11/07/1934 and numbered 15319/107, based on the letter of the Ministry of Education dated 11/04/1934 and numbered 94041, which summarizes said letters by the Ministry of Education and the Directorate General of Foundations, converted the Hagia Sophia into a mosque by providing: "The matter has been discussed by the Cabinet on 11/24/1934 and it has been approved and decided that the waqf buildings surrounding the mosque be demolished and cleaned by the Directorate General of Foundations and that the other buildings be expropriated and the Hagia Sophia Mosque be converted into a museum with the cost of demolishing, reparation and preservation being paid by the Ministry of Education." 


\section{2) The Waqf Charter}

It has been emphatically stated in the waqf charter of Mehmed II son of Murad II's waqf dated 1470 that among the charities of the waqf is the Hagia Sophia Mosque, previously a church, and that the condition is irrevocable that "waqf properties shall in no way be transferred or acquired."

\section{3) The Deed}

Hagia Sophia, after the Cabinet Decision in question was put into place, in accordance with the deed dated 11/19/1936, was registered under the name of the "Ebulfetih Sultan Mehmet Waqf" (today Fatih Sultan Mehmet Han Waqf) as located in the City of Istanbul, District of Eminonu, Cankurtaran Neighborhood, Bab-i Humayun Street, in lot no. 7, block no. 57, section no. 57, as "The Honorable Mosque of Grand Hagia Sophia inclusive of a tomb, properties rented out, a clockhouse, and a madrasa." The Hagia Sophia Mosque is an immovable charity, endowed according to the private law regulations of the Ottoman State, that belongs to the waqf of Mehmed II son of Murad II.

\section{4) The Convention Concerning the Protection of the World Cultural and Natural Heritage}

In accordance with the rules of the Convention Concerning the Protection of the World Cultural and Natural Heritage, to whose accession we have provided assent through the Law dated 04/14/1982 and numbered 2658, adopted by the Cabinet Decision dated 05/23/1982 and numbered 8/4788 and published in the Official Gazette dated 02/14/1983 and numbered 17959, without any specification as to its use, Hagia Sophia was included in the World Heritage List on 12/06/1985 under the title "Istanbul's Historic Sites," together with other historic sites 
on the historical peninsula, including the Topkapi Palace, the Suleymaniye Mosque, the Blue Mosque, the Sehzade Mehmet Mosque, Zeyrek Mosque, and others. The World Heritage List, prepared in line with said Convention's provisions, reflects the natural and cultural sites determined by UNESCO's World Heritage Committee and whose protection is guaranteed by the states in which they are located.

Article 6 of said Convention provides: "Whilst fully respecting the sovereignty of the States on whose territory the cultural and natural heritage mentioned in Articles 1 and 2 is situated, and without prejudice to property right provided by national legislation, the States Parties to this Convention recognize that such heritage constitutes a world heritage for whose protection it is the duty of the international community as a whole to co-operate."

\section{5) Assessment}

(I) ConCERNing InTERNATional LAW

It is obvious that, in light of Article 6 of the Convention Concerning the Protection of the World Cultural and Natural Heritage, State parties to the Convention accept that Hagia Sophia's cultural and natural heritage should be protected through international cooperation without any prejudice to the sovereignty of the Republic of Turkey where it is located and to the ownership rights granted by Turkey's domestic laws.

Thus, there is nothing in the Convention prohibiting a determination, based on our domestic laws, on how to use Hagia Sophia, which has been included in the World Heritage List without any specification as to its use. On the contrary, it is a necessity of "respecting the sovereignty of States" and "without prejudice to property right provided by national legislation" provisions of Article 6 of the Convention that the use of Hagia Sophia be determined according to our domestic law on founda- 
tions.

While the Convention's essential purpose is to protect the natural and cultural sites included in the World Heritage List, cultural sites' field of use is to be determined by the domestic law of the country in which the cultural site is located. Indeed, there are many heritage sites within "Istanbul's Historic Sites," among which is Hagia Sophia, and other heritage sites which have sites still being used as mosques, including the Selimiye Mosque, Divrigi Ulu Mosque, the Suleymaniye Mosque the Blue Mosque, the Sehzade Mehmet Mosque, and Zeyrek Mosque.

\section{(II) Concerning Domestic LaW}

Immovable charities [tr. hayrat] are waqf immovables that are established for direct public use such as places of worship, hospitals, and kitchens. According to both the repealed Waqf Law numbered 2762 and the in-force Waqf Law numbered 5737, these immovables have been reserved for "public use."

Therefore, in essence, private ownership law does not apply to these immovables; immovable charities cannot be sold, pledged, confiscated, nor can any statute of limitations granting proprietary interests thereon can be instituted.

For these properties fall under no one's private ownership but are assigned to public use and benefit. Except for situations provided in Article 10 of the repealed Waqf Law numbered 2762 and Articles 15 and 16 provided in the Waqf Law 5737, immovable charities cannot be assigned a different purpose other than the one determined by the waqf. Even under said exceptions, immovable charities must be assigned to other charities with a similar purpose, to the extent possible.

The foundational quality of a waqf's immovable charities is that they are protected from out-of-purpose use against third persons as well as the state itself. That these waqfs are under the protection of the state does not mean that the state may dispose of waqf properties whenever and as it pleases. The state 
is merely an entity to whom waqf property is entrusted to ensure that the property is used only in line with its purpose.

Assigning a waqf's immovable charities a different purpose via a regulatory administrative measure will offend both domestic law and universal legal principles.

Article 1 of the repealed Law on the Application and Enforcement of the Civil Code numbered 864, which governs the applicable law to waqfs established before the entry into force of the Turkish Civil Code, clearly provides: "Events that preceded the entry into force of the civil code shall be governed by law applicable at the time of occurrence of said events." Article 8 clearly provides: "A separate enforcement law shall be passed concerning waqfs established before the entry into force of the civil code." Although these provisions explicitly protect "old waqf status," -which can be said to be formulated as follows:

(i) That the provisions of the founding document vakfiye, upon the establishment of the waqf has been completed, binds the endower, the trustees, the beneficiaries, third parties as well as the state,

(ii) That the matters regulated by the vakfiye can in no way be changed,

(iii) That it is obligatory that waqf properties be used in accordance with the intention of the endower-when the disputed Cabinet Decision is examined, it becomes clear that the immovable charity Hagia Sophia Mosque, which, according to its vakfiye, ought to have been used as a mosque, and which, according to the deed, belongs to the "Ebulfetih Sultan Mehmet Waqf" (today Fatih Sultan Mehmet Han Waqf), has been converted into a museum.

The old waqf status of the Hagia Sophia Mosque and waqfs established prior to the entry into force of the Turkish Civil Code on 4 October 1926, which was protected by Articles 1 and 8 of the Law numbered 864 , has been preserved continually based on the same principles by the repealed Waqf Law dated 06/05/1935 and numbered 2762, the Law on the Application 
and Enforcement of the Turkish Civil Code dated 12/03/2001 and numbered 4722, and the Waqf Law dated 02/20/2008 and numbered 5737, all of which have come into force after the disputed Cabinet Decision. Thus, the Cabinet Decision in question is clearly inconsistent with Article 1 of the Law numbered 864 quoted above, which provides that the law at the time of the writing of the waqf charter shall be applicable law.

When the Cabinet Decision in question is examined in light of the aforementioned legal framework and the decisions of the Constitutional Court, the Court of Cassation, the Council of State, and the ECHR, it is undisputed that;

Hagia Sophia, whose status is preserved and guaranteed by our legal order, is under the ownership of the mazbut waqf Fatih Sultan Mehmet Han Waqf with its own private law legal personality,

Hagia Sophia has been assigned to public use as a mosque in accordance with its endower's intention, that it is an immovable charity reserved for the benefit of the public free of charge, and that it is also registered in its deed as a mosque,

The waqf charter has the force and value of law, that the quality and intended use of the endowed immovable stated in the waqf charter cannot be altered and that this binds all real and legal persons, including Respondent,

The state has a positive obligation to ensure that waqf assets are used in accordance with the intent of the endower and a negative obligation not to interfere with waqf property and rights that would do away with the intent of the endower.

In this case, because it is concluded that the Waqf'swhich has been preserved and protected by the Turkish legal system since ancient times-immovables and rights cannot be prohibited from being left to public use in line with its charter and that it is legally impossible for it to be put to a different use, as it has been perpetually assigned per the waqf charter to be used as a mosque, there is no legality in the disputed Cabinet Decision that, disregarding all of this, has ended Hagia Sophia's 
use as a mosque and converted it into a museum.

\section{DECISION:}

For the foregoing reasons, with the possibility of appeal to the Council of Chambers of Administrative Matters within 30 days of receipt of this decision, it has been decided unanimously on $07 / 02 / 2020$ that;

1. The disputed Cabinet Decision be ANULLED,

2. The litigation expenses, whose details are provided below, totaling [Redacted] be paid by Respondent to Plaintiff,

3. [Redacted] Turkish Lira attorney fees according to the Attorney Minimum Fee Guidelines applicable at the time of the decision be paid by Respondent to Plaintiff,

4. The remainder of the postal fee down payment be returned to Plaintiff after the decision becomes final. 